\title{
Effects of Curcumin Supplementation on Viability and Antioxidant Capacity of Buffalo Granulosa Cells under In Vitro Culture Conditions
}

\author{
Nasser Ghanem ${ }^{1,2 *}$, Ahmed Amin ${ }^{1}$, Ayman Moustafa Saeed ${ }^{3}$, Sherif M. Abdelhamid ${ }^{3}$, Ashraf El-Sayed ${ }^{1,5}$, Omar A. \\ Farid $^{4}$, Sherif M. Dessouki ${ }^{1}$ and Marwa S. Faheem ${ }^{1,2}$ \\ ${ }^{I}$ Department of Animal Production, Faculty of Agriculture, Cairo University, Giza, Egypt. \\ ${ }^{2}$ Cairo University Research Park (CURP), Faculty of Agriculture, Cairo University, Giza, Egypt. \\ ${ }^{3}$ Biotechnology Research Department, Animal Production Research Institute, Agriculture Research centre, Dokki, Giza, Egypt \\ ${ }^{4}$ National Organizations for Drug Control and Research, Giza, Egypt. \\ ${ }^{5}$ King Abdullaziz University, Jeddah, kingdom of Saudi Arabia. \\ *Corresponding author's Email: nassergo@agr.cu.edu.eg; (DORCID: 0000-0002-0480-0959
}

\begin{abstract}
The current study was conducted to investigate the possible protective effect of curcumin supplementation on buffalo granulosa cells (GCs) under in vitro culture condition. Buffalo ovaries were collected from local abattoir in physiological saline solution and transported directly to laboratory. Follicular fluid containing GCs and cumulusoocyte-complexes were aspirated from antral follicles with diameter $2-8 \mathrm{~mm}$. The collected GCs were seeded (Approximately 375,000 viable cells) in an 8-well culture plate containing tissue culture medium-199 (TCM-199) and kept at $37{ }^{\circ} \mathrm{C}$ in a humidified atmosphere of $5 \% \mathrm{CO}_{2}$. The curcumin was supplemented to TCM media at levels of $1,2.5,5$ and $10 \mu \mathrm{M}$ for 24 and $48 \mathrm{~h}$ at $37^{\circ} \mathrm{C}$ or kept without treatment as control group. The viability of cells was determined using the trypan blue test. Intracellular reactive oxygen species (ROS) level was assessed by measuring the fluorescent intensity of 6-carboxy-2',7'-dichlorodihydro fluorescein diacetate $\left(\mathrm{H}_{2} \mathrm{DCFDA}\right)$. In addition, mitochondrial activity of GCs was determined. The results of the present study indicated that the viability of GCs under culture conditions was significantly decreased in groups treated with $1,2.5,5$ and $10 \mu \mathrm{M}$ curcumin $(86.0 \%$, $86.26 \%, 83.0 \%$ and $74.0 \%$, respectively) compared to control group $(93.60 \%)$. The two groups of granulosa cells cultured with 2.5 and $5 \mu \mathrm{M}$ curcumin recorded greater level of mitochondrial activity than the groups cultured with $1 \mu \mathrm{M}$ and $10 \mu \mathrm{M}$ curcumin. Moreover, there was a significant increase in ROS level in group cultured with $10 \mu \mathrm{M}$ curcumin, compared to control and other experimental groups. The enzyme activity of catalase (CAT), superoxide dismutase (SOD), glutathione (GSH) and 1, 1-diphenyl-2-picrylhydrazyl (DPPH) was increased after treating in vitro cultured granulosa cells with $5 \mu \mathrm{M}$ of curcumin. However, the enzymatic activity of CAT, SOD, GSH and DPPH was declined significantly $48 \mathrm{~h}$ post-curcumin treatment. In conclusion, supplementation of curcumin at low concentration $(2.5 \mu \mathrm{M})$ for $24 \mathrm{~h}$ to in vitro cultured GCs improved intracellular metabolic activity and antioxidant protective system, whereas it could not sustain this action for $48 \mathrm{~h}$. Moreover, supplementation of curcumin at high concentration and for long duration may negatively affect viability of GCs under in vitro culture condition via induction of oxidative stress.
\end{abstract}

Key words: Antioxidant, Buffalo, Granulosa cells, Oxidative stress, Viability.

\section{INTRODUCTION}

Oxidative stress, mediated by oxygen-derived free radicals (also known as reactive oxygen species, ROS) is a frequent state affecting nearly all living organisms because of suboptimal environmental conditions. In homeostatic situation, there is stability between the production of ROS and scavenging power of cells through the cellular antioxidant system (Panieri et al., 2016). Nevertheless, when the production of ROS overcomes the cellular antioxidant capability, it perhaps contributes to a problem referred to oxidative stress (Agarwal et al., 2005). The ROS level could be elevated endogenously during many physiological and reproductive procedures including ovulation (Agarwal et al., 2005; Gupta et al., 2010). Moreover, the use of oxygen as a respiratory substrate was reported to produce oxidative stress throughout the aerobic metabolic process and energy production (Frisard and Ravussin, 2006). Furthermore, other endogenous sources (mitochondria, inflammatory cell activations, plasma membrane nicotinamide adenine dinucleotide phosphate, oxidase, lysosomes, and peroxisomes) may affect the production of ROS in mammalian cells (Klaunig et al., 2009).

Incidence of oxidative stress mediated by ROS was found to be having a negative effect on female reproductive system and finally causes infertility (Agarwal et al., 2012). Ovarian granulosa cells (GCs), the major cellular constituent in a follicle, have two vital functions in female reproduction: steroid production and defend the oocyte throughout ovulation (Yada et al., 1999; Sohel et al., 2013; Cinar and Sohel, 2015). At the end of follicular growth, GCs in the dominant follicle are differentiated into luteal cells by an ovulatory luteinizing hormone (LH) surge (Duffy and Stouffer, 
2003). This method is crucial for successful ovulation and formation of corpus luteum to keep the pregnancy. On the other hand, all through ovulation after the pre-ovulatory rise of LH, inflammatory cells particularly neutrophils and macrophages are vastly hired to produce ROS to facilitate follicular rupture and the release of the oocyte (Shkolnik et al., 2011), indicating exposure of GCs to some sort of oxidative stress during ovulation. In addition to an endogenous source, environmental sources of ROS could make the situation more complex.

One of the plants efficiently used in folk medicine is Curcuma longa Linn (Hatcher et al., 2008). In this herb, curcumin component has the highest proportion (Aggarwal et al., 2007). Curcumin is a yellow polyphenol compound found in turmeric (Esatbeyoglu et al., 2012), and its chemical structure is 1, 7-bis (4-hydroxy-3- methoxyphenyl)-1, 6eptadiene-3, 5-dione (Nadkarni, 2007; Kádasi et al., 2012). It has proven to be a highly effective anti-carcinogenic, antiviral, antioxidant (Steward et al., 2008; Correa et al., 2013; Tapia et al., 2013), and anti-inflammatory substance in human and animal models (Epstein et al., 2010; Sung et al., 2012).

Curcumin acts as an antioxidant since it scavenges reactive oxygen and nitrogen species (Barzegar and MoosaviMovahedi, 2011; Trujillo et al., 2013 ; Mohebbati et al. 2017) and induces cytoprotective enzymes such as glutathioneStransferase (GST), $\gamma$-glutamyl cysteine ligase ( $\gamma$-GCL) and heme oxygenase-1 (HO-1) (Dinkova-Kostova et al., 2008; Reyes-Fermín et al., 2012). It is able to scavenge hydrogen peroxide, peroxyl radicals, superoxide anion, hydroxyl radicals, singlet oxygen, nitric oxide, and peroxynitrite anion (Trujillo et al., 2013). It has been revealed that curcumin causes endogenous antioxidant defense systems by modulating transcription factors such as nuclear factor (erythroidderived 2)-like 2 (Nrf2) (Tapia et al., 2012; Liu et al. 2016; Zhang et al., 2019a; Zhang et al., 2019b; Zhu et al., 2020), activator protein-1 (AP-1), and nuclear factor kappa B (NFKB) (Pinkus et al., 1996). Therefore, the aim of this study was to investigate the effects of curcumin supplementation to in vitro culture media of buffalo GCs on their viability and enzymatic defense system.

\section{MATERIALS AND METHODS}

\section{Experimental groups}

A primary culture of GCs was used as a basic technique to study the effects of curcumin supplementation on buffalo GCs cultured in vitro in TCM-199 medium. Primary cultures of GCs were grown in six groups. The groups were divided as the following: group 1: untreated (control), group 2: untreated control and add dimethyl sulfoxide (DMSO) (it is the dissolving solution for curcumin), group 3: treated only with $1 \mu \mathrm{M}$ curcumin, group 4: treated only with $2.5 \mu \mathrm{M}$ curcumin, group 5: treated only with $5 \mu \mathrm{M}$ curcumin and group 6: treated only with $10 \mu \mathrm{M}$ curcumin. The recovered cells were grown until they reached up to $40-50 \%$ confluency before being allocated into the different treatment groups. A minimum of 10 ovaries were used in each biological replicate. Three biological replicates of GCs were used for each experimental assay done in this study.

\section{Collection of ovaries and granulosa cells}

Granulosa cells were collected and cultured according to the procedure described by Sohel et al. (2017). A total of 120 buffalo ovaries were obtained from a local slaughterhouse, and transported in $0.9 \%$ saline solution at $37{ }^{\circ} \mathrm{C}$ within 2 $\mathrm{h}$ of collection. A minimum of 10 ovaries were used in each replicate in order to obtain a sufficient number of GCs for different assays. Ovaries were washed twice with $0.9 \%$ saline solution and then washed once with $70 \%$ ethanol. The follicular contents (follicular fluid containing GCs and cumulus-oocyte complexes) were aspirated from antral follicles of 2-8 $\mathrm{mm}$ in diameter by an 18-gauge needle attached to a 5-mL syringe and placed in a 50 - $\mathrm{mL}$ sterile falcon tube containing 10-mL TCM-199 medium (Sigma- Aldrich, M5017, Steinheim, Germany). After collection, tubes were left for $15 \mathrm{~min}$ at $37{ }^{\circ} \mathrm{C}$ to allow the oocyte-cumulus complexes and cellular debris to settle at the bottom of the tube. The upper liquid containing GCs was then collected in a $15-\mathrm{mL}$ falcon tube, and centrifuged at $1800 \mathrm{rpm}$ for $5 \mathrm{~min}$ to obtain the GCs. The collected GCs were washed with $5 \mathrm{ml}$ of phosphate buffer saline (PBS) that is free from calcium magnesium by repeat pipetting followed by centrifugation at $1500 \mathrm{rpm}$ for $10 \mathrm{~min}$. Finally, $3 \mathrm{ml}$ of trypsin was added and the tube incubated at $37^{\circ} \mathrm{C}$ for $3 \mathrm{~min}$, then $5 \mathrm{ml}$ of TCM-199 was added to inactivate trypsin by repeat pipetting of GCs followed by centrifugation at $1500 \mathrm{rpm}$ for $10 \mathrm{~min}$.

\section{In vitro culture and treatment of granulosa cells}

Approximately 375,000 viable cells were seeded in an 8-well culture plate (Corning Incorporated, Kennebunk, ME, USA), in vitro culture in medium containing TCM-199 medium (Sigma-Aldrich, D6046, Steinheim, Germany) supplemented with $10 \%$ fetal bovine serum (vol/vol), penicillin $(100 \mathrm{U} / \mathrm{mL})$ and streptomycin $(100 \mu \mathrm{g} / \mathrm{mL})(\mathrm{Sigma}$ Aldrich, P4333, Steinheim, Germany) and kept at $37{ }^{\circ} \mathrm{C}$ in a humidified atmosphere of $5 \% \mathrm{CO}_{2}$ until reached $40-50 \%$ confluency. The curcumin was added to the TCM-199 medium at the following levels (Control, DMSO, $1 \mu \mathrm{M}, 2.5 \mu \mathrm{M}, 5$ $\mu \mathrm{M}$ and $10 \mu \mathrm{M})$ for $48 \mathrm{~h}$ with change the medium once after $24 \mathrm{~h}$. 


\section{Cell morphology and viability}

After treatment, GCs from different treatment groups were observed using inverted microscopy for confluency and changes in morphology. The viability of cells was determined using the trypan blue exclusion test as described by Strober (2015) with some modifications. Briefly, after the treatment, both adherent and floating cells from each treatment group were collected and resuspended in one $\mathrm{mL}$ of in vitro culture medium. Following that, $100 \mu \mathrm{L}$ of cell suspension and $100 \mu \mathrm{L}$ of $0.4 \%$ trypan blue were mixed into a micro-centrifuge tube and incubated for $1-2$ min at room temperature. Ten microliters of cell mixture/ trypan blue were applied to the hemocytometer and placed under a microscope (Inverted Microscope, Leica DMI 3000B, Wentzler, Germany) at magnification of 20X for counting live and dead cells. GC viability was calculated as a percentage of viable cells from total cell count.

\section{Cytotoxicity assay}

In the present study, the neutral red uptake assay supplies a quantitative estimation of how many feasible cells in culture. It is one of the most applied cytotoxicity tests with many biomedical and environmental applications. It is based on the ability of viable cells to incorporate and bind the supravital dye neutral red in the lysosomes. The granulosa cells were seeded in 96-well tissue culture plates and were treated for the appropriate period. The plates were incubated for 2 $\mathrm{h}$ with a medium containing neutral red. The cells were subsequently rinsed with media, the dye was removed properly and the absorbance was read using a spectrophotometer. Once the cells have been treated, the assay can be completed in $<3 \mathrm{~h}$ (Repetto et al., 2008).

\section{Intracellular reactive oxygen species detection}

Intracellular ROS accumulation in different treatments and control group was assessed by 6-carboxy-2', 7'dichlorodihydro fluorescein diacetate $\left(\mathrm{H}_{2}\right.$ DCFDA, Sigma-Aldrich, USA) according to the protocol described by Sohel et al. (2017). The GCs from each group were incubated with $400 \mu \mathrm{L}$ of $15 \mu \mathrm{M} \mathrm{H}_{2} \mathrm{DCFDA}$ for 20 min in the dark at $37{ }^{\circ} \mathrm{C}$. Cells were then washed twice with PBS and images were immediately captured with a Nikon Eclipse Ti-S microscope (Nikon Instruments Inc., Tokyo, Japan) using a green-fluorescence filter at excitation/emission: 492-495/517-527 nm and images were acquired by NIS Elements software. For quantitative analysis, the mean fluorescence intensity of five non-overlapping fields in each well was measured using Image J software (Rueden et al., 2017). Data are presented as mean \pm standard deviation.

\section{Mitochondrial activity}

Mitochondrial activity of buffalo GCs was determined using MitoTracker Red CMXRos (M7512, Invitrogen, Karlsruhe, Germany) according to the previous published protocol (Prastowo et al., 2017) with small modifications. The GCs from each group were incubated with $15 \mu \mathrm{L}$ of 200-nM MitoTracker red dye for 45 min, followed by two washings with PBS and were then fixed overnight at $4{ }^{\circ} \mathrm{C}$ with $4 \%$ formaldehyde. The mitochondrial activity of GC samples was visualized under a laser scanning confocal microscope (LSM 710; Carl Zeiss, Germany) using specific excitation lasers at $579-599 \mathrm{~nm}$. A constant level of laser gain (master gain = 700), pinhole $(1 \mu \mathrm{m})$ and pixel size $(1024 \times 1024)$ were applied during image acquisition aim to allow image fluorescence signal comparison. Resulted images were then processed using ZEN 2011 software (Carl Zeiss, Germany). For quantitative analysis, the mean fluorescence intensity of five non-overlapping fields in each well was measured using Image J software. Data are presented as mean \pm SD.

\section{Enzyme activity}

\section{1, 1-Diphenyl-2-picrylhydrazyl (DPPH*) radical scavenging assay}

The ability of different extracts to act as hydrogen donors was measured by DPPH radical scavenger activity. The assay was carried out according to method of Blois (1958). The DPPH, a stable free radical, contains an odd electron, which is responsible for the absorbance at 515-517 $\mathrm{nm}$ and for a visible deep purple color. When DPPH accepts an electron from an antioxidant compound, it is reduced to 1,1-diphenyl-2-picrylhydrazine (decolorized non-radical, DPPH2).

\section{Determination of superoxide dismutase (SOD) activity}

SOD activity was assayed in the liver tissue by the method of Marklund and Marklund,(1974) at $420 \mathrm{~nm}$ for $1 \mathrm{~min}$ on a Shimadzu UV-2450 spectrophotometer (Shimadzu, Kyoto, Japan). Activity was expressed as the amount of enzyme that inhibits the autoxidation of pyrogallol by $50 \%$, which is equal to $1 \mathrm{U} / \mathrm{mg}$ protein.

Determination of catalase (CAT) activity

The activity of CAT was measured by spectrophotometric method based on the decomposition of $\mathrm{H}_{2} \mathrm{O}_{2}$ as described by Aebi (1984).

\section{Determination the profile of GSSG and GSH by HPLC}

The thiols compounds of oxidized and reduced glutathione were detected by HPLC using the method of Jayatilleke and Shaw (1993). Glutathione (oxidized and reduced) reference standard purchased from Sigma-Aldrich Chemical Co (G4376, USA). The powder of glutathione was dissolved in $75 \%$ methanol in a stock of $1 \mathrm{mg} / \mathrm{ml}$ and diluted before application to HPLC. The HPLC system of Agilent (Santa Clara, USA) consisted of quaternary pump, a column oven, 
Rheodine injector and $20 \mu \mathrm{l}$ loop, UV variable wavelength detector. The report and chromatogram taken from Chemstation program purchased from Agilent. Synerji RP Max column 3.9 at wavelength 210 nm with flow rate $2 \mathrm{ml} / \mathrm{min}$ was used. Pot. Phosphate buffer - acetonitrile at $\mathrm{pH} 2.7$ was used as an isocratic mobile phase.

Determination of adenosine tri-phosphate content in media by HPLC (1993)

The detection of adenosine tri-phosphate (ATP) by HPLC was done according to the method of Teerlink et al.

\section{Statistical analysis}

A minimum of three biological replicates was used in each experiment per each essay (number of each replicate $=$ $3 \mathrm{n}$ and total number of replicates $=72 \mathrm{n}$ ). Statistical differences of means were compared between different experimental groups and were analyzed by applying one-way ANOVA, followed by Duncan's multiple range test that was used to detect differences among means. Differences in values of means were considered significant at $\mathrm{P} \leq 0.05$. The General Linear Model (GLM) procedure on SAS Software (SAS, 2004) was used for statistical analysis. Data are supposed to be normally distributed and were expressed as mean \pm SD of three biological replicates.

The parameters were analyzed according to the following model:

$Y_{\mathrm{ijk}}=\mu+\mathrm{A}_{\mathrm{i}}+\mathrm{e}_{\mathrm{ij}}$.

$\mathrm{Y}_{\mathrm{ijk}}=$ the measured trait.

$\mu=$ Overall means.

$\mathrm{A}_{\mathrm{i}}=$ The Effect of different levels of curcumin.

$\mathrm{e}_{\mathrm{ij}}=$ Experimental error.

\section{RESULTS}

\section{Viability}

The viability of in vitro cultured granulosa cells (figure 3 ) was significantly decreased $(\mathrm{p} \leq 0.05)$ on groups treated with DMSO (88.0 $\pm 1.6 \%), 1 \mu \mathrm{M}$ curcumin $(86.0 \pm 1.6 \%), 2.5 \mu \mathrm{M}$ curcumin $(86.26 \pm 1.6 \%), 5 \mu \mathrm{M}$ curcumin $(83.0 \pm 1.6 \%)$ and $10 \mu \mathrm{M}$ curcumin $(74.0 \pm 1.6 \%)$ compared to control group $(93.60 \pm 1.6 \%)$.

\section{Mitochondrial activity}

There were no significant differences in mitochondrial activity of granulosa cells cultured with DMSO, $2.5 \mu \mathrm{M}$ curcumin and control group (Figures 2 and 4). In addition, there was no significant difference in the activity of mitochondria between the group cultured with $2.5 \mu \mathrm{M}$ curcumin and $5 \mu \mathrm{M}$ curcumin. Moreover, the two groups cultured with $1 \mu \mathrm{M}$ curcumin and $10 \mu \mathrm{M}$ curcumin did not show differences on mitochondrial activity. However, the two groups of granulosa cells cultured with $2.5 \mu \mathrm{M}$ and $5 \mu \mathrm{M}$ curcumin recorded higher level of mitochondrial activity than the groups cultured with $1 \mu \mathrm{M}$ and $10 \mu \mathrm{M}$ curcumin.

\section{Reactive oxygen species (ROS) level}

There were no significant differences on ROS level of granulosa cells cultured with DMSO, $1 \mu \mathrm{M}$ and $2.5 \mu \mathrm{M}$ curcumin group (Figures 1 and 5). However, there was a significant $(\mathrm{p} \leq 0.05)$ increase in ROS level in group cultured with $10 \mu \mathrm{M}$ curcumin compared to control and other treatments. In addition, the group of granulose cells cultured with $5 \mu \mathrm{M}$ curcumin recorded higher level of ROS than the groups cultured with $1 \mu \mathrm{M}, 2.5 \mu \mathrm{M}$ and $10 \mu \mathrm{M}$ curcumin.

\section{Activity of 1, 1-diphenyl-2-picrylhydrazyl (DPPH) in in vitro cultured granulosa cells}

There were no significant differences on DPPH radical scavenger activity of granulose cells cultured with DMSO, $2.5 \mu \mathrm{M}$ after $48 \mathrm{~h}, 5 \mu \mathrm{M}$ after $48 \mathrm{~h}, 10 \mu \mathrm{M}$ after 48 hand $1 \mu \mathrm{M}$ after $24 \mathrm{~h}$ cultured of curcumin (Figure 6). In addition, there was no significant difference between granulose cells cultured with $1 \mu \mathrm{M}$ after $48 \mathrm{~h}, 10 \mu \mathrm{M}$ after $24 \mathrm{~h}$ and $2.5 \mu \mathrm{M}$ after $24 \mathrm{~h}$ cultured of curcumin. In addition, there was a significant difference between the granulose cells cultured as a control group and $5 \mu \mathrm{M}$ curcumin group for $24 \mathrm{~h}$. However, the two groups of granulose cells cultured with $5 \mu \mathrm{M}$ curcumin for 24 hours and $1 \mu \mathrm{M}$ curcumin for $48 \mathrm{~h}$ recorded high level of DPPH radical scavenger activity in compared with other groups.

\section{Activity of superoxide dismutase (SOD) in in vitro cultured granulosa}

There were significant differences on SOD activity between the granulose cells cultured in control group and experimental groups supplemented with curcumin (Figure 7). The maximum activity of SOD was recorded in granulose cells cultured with $5 \mu \mathrm{M}$ curcumin for $24 \mathrm{~h}$ compared to control group that had the lowest activity of this enzyme. In addition, there were no significant differences on SOD activity of granulose cells cultured with DMSO, $1 \mu \mathrm{M}$ curcumin for $24 \mathrm{~h}, 2.5 \mu \mathrm{M}, 5 \mu \mathrm{M}$, and $10 \mu \mathrm{M}$ curcumin for $48 \mathrm{~h}$. In addition, too no significant difference of granulose cells cultured $2.5 \mu \mathrm{M}$ curcumin for $24 \mathrm{~h}, 5 \mu \mathrm{M}$ curcumin for $24 \mathrm{~h}$ and $1 \mu \mathrm{M}$ curcumin for $48 \mathrm{~h}$, As noted the group of granulose cells cultured with $5 \mu \mathrm{M}$ curcumin for $24 \mathrm{~h}$ recorded higher level of SOD activity than other experimental groups. 


\section{Activity of catalase in in vitro cultured granulosa cells}

There were significant differences on CAT activity between the granulose cells cultured as a control group, DMSO and $5 \mu \mathrm{M}$ curcumin groups for $24 \mathrm{~h}$ (Figure 8). In addition, no significant differences on CAT activity of granulose cells cultured DMSO, $1 \mu \mathrm{M}$ curcumin for $24 \mathrm{~h}, 2.5 \mu \mathrm{M}$ curcumin for $24 \mathrm{~h}, 10 \mu \mathrm{M}$ curcumin for $24 \mathrm{~h}, 1 \mu \mathrm{M}, 2.5 \mu \mathrm{M}, 5 \mu \mathrm{M}$, and $10 \mu \mathrm{M}$ curcumin for $48 \mathrm{~h}$. As noted, the group of granulose cells cultured with $5 \mu \mathrm{M}$ curcumin for $24 \mathrm{~h}$ recorded higher level of SOD activity than the others groups.

\section{Activity of glutathione in in vitro cultured granulosa cells}

There were significant differences $(\mathrm{P}<0.05)$ on GSH activity between the granulose cells cultured control group, DMSO and $5 \mu \mathrm{M}$ curcumin for $24 \mathrm{~h}$ (Figure 9). As noted, the group of granulose cells cultured with $5 \mu \mathrm{M}$ curcumin for $24 \mathrm{~h}$ recorded higher level of SOD activity than the others groups.

\section{Activity of oxidized glutathione in in vitro cultured granulosa cells}

There was a significant $(\mathrm{P}<0.05)$ decline in GSSG level on groups treated with curcumin at concentration of $5 \mu \mathrm{M}$ and $10 \mu \mathrm{M}$ after $24 \mathrm{~h}$ of culture in addition the same trend was observed in granulosa cells treated with curcumin at concentration of $1 \mu \mathrm{M}$ after $48 \mathrm{~h}$ compared to all experimental groups (Figure 10). However, the highest level of this enzyme was recorded in control group.

\section{Intracellular adenosine triphosphate content in in vitro cultured granulosa cells}

There were significant differences $(\mathrm{P}<0.05)$ on CAT activity between the granulose cells cultured in control group, DMSO and $5 \mu \mathrm{M}$ curcumin for $24 \mathrm{~h}$ (Figure 11). The content of ATP was increased gradually and significantly (P $<0.05$ ) in ascending pattern in GCs and reached the maximum profile after $24 \mathrm{H}$ in the group cultured with $5 \mu \mathrm{M}$. After that, the profile of ATP was decreased $(\mathrm{P}<0.05)$ in GCs cultured with curcumin at concentration of 5 and $10 \mu \mathrm{M}$ for 48 h. The lowest profile of ATP was recorded in control group.

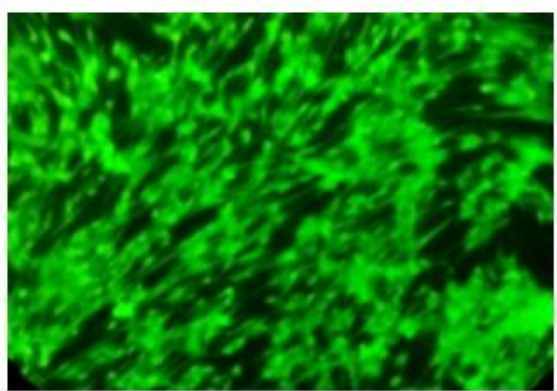

Cont

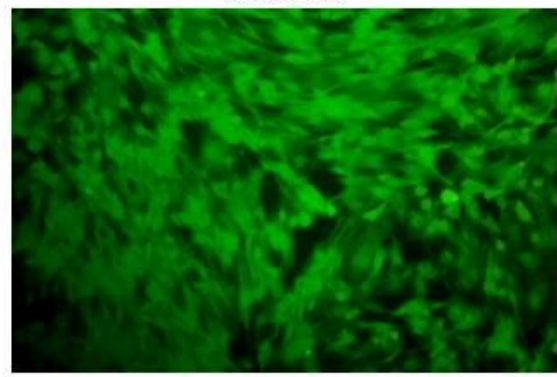

1 uM

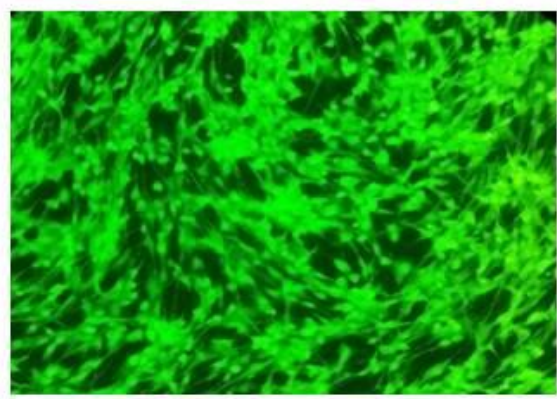

5 uM

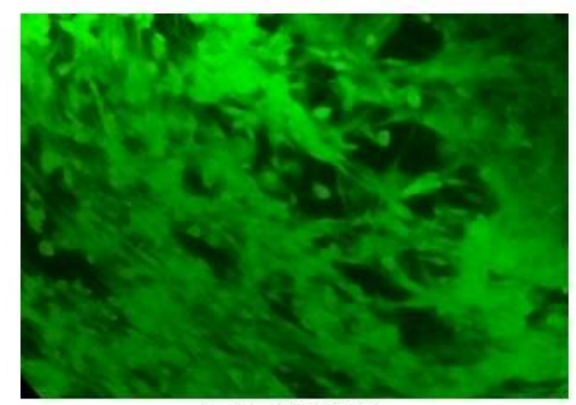

DEMSO

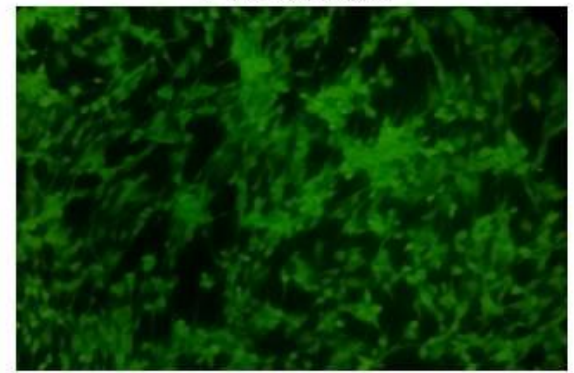

2.5uM

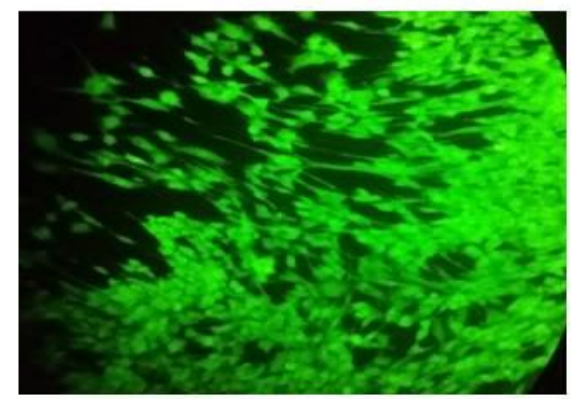

$10 \mathrm{uM}$

Figure 1. Image of in vitro cultured granulosa cells stained with $\mathrm{H}_{2}$ DCFDA measuring the level of reactive oxygen species (ROS) after supplementation with different concentrations of curcumin $(1,2.5,5$ and $10 \mu \mathrm{M})$ after $24 \mathrm{~h}$. The image was taken by inverted microscope (Leica DMI 3000B, Wentzler, Germany) at magnification of 20X. 


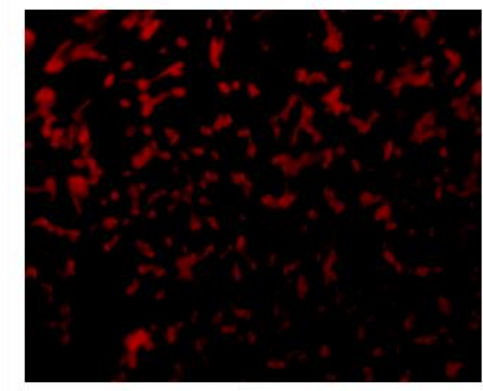

Cont

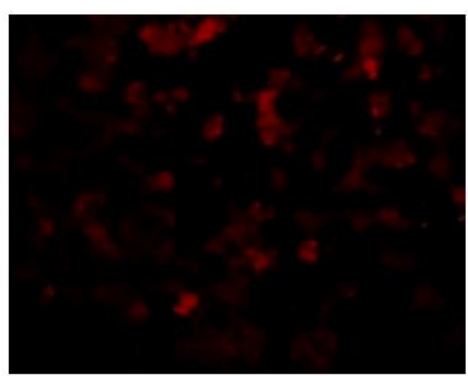

1 uM

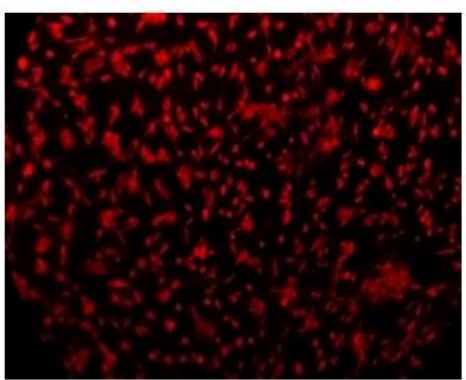

5 uM

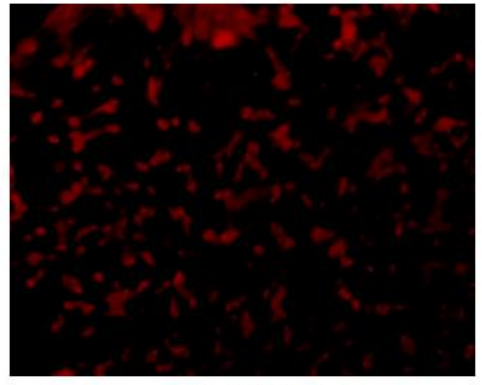

DEMSO

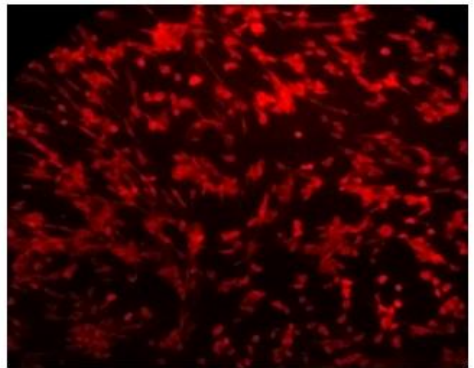

2.5 uM

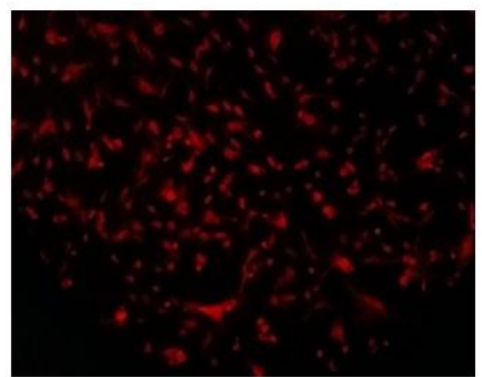

$10 \mathrm{uM}$

Figure 2. Image of in vitro cultured granulosa cells stained with mitotraker red measuring mitochondrial activity after supplementation with different concentrations of curcumin $(1,2.5,5$ and $10 \mu \mathrm{M})$ after $24 \mathrm{~h}$. The image was taken by inverted microscope (Leica DMI 3000B, Wentzler, Germany) a magnification of 20X.

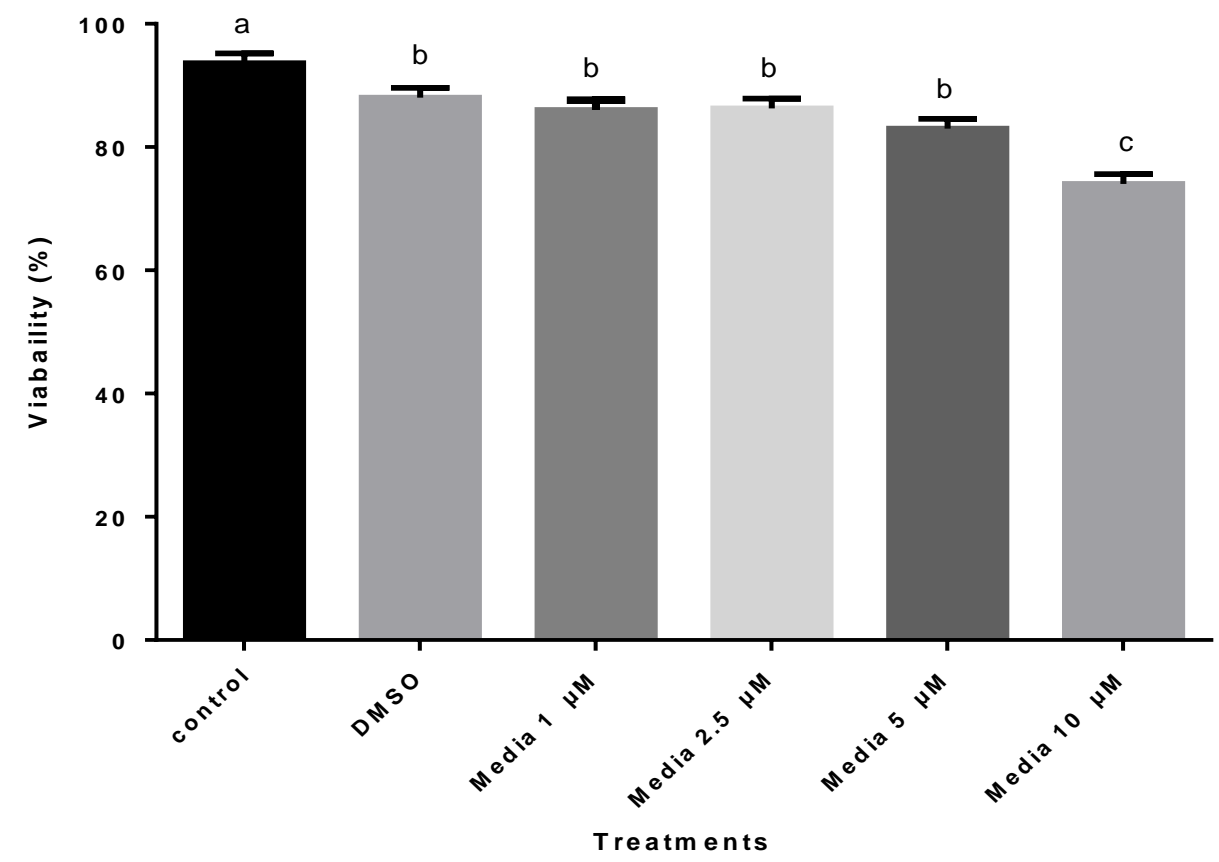

Figure 3. Viability of in vitro cultured granulosa cells treated with different concentrations of curcumin $(1,2.5,5$ and 10 $\mu \mathrm{M})$ after $24 \mathrm{~h}$. 


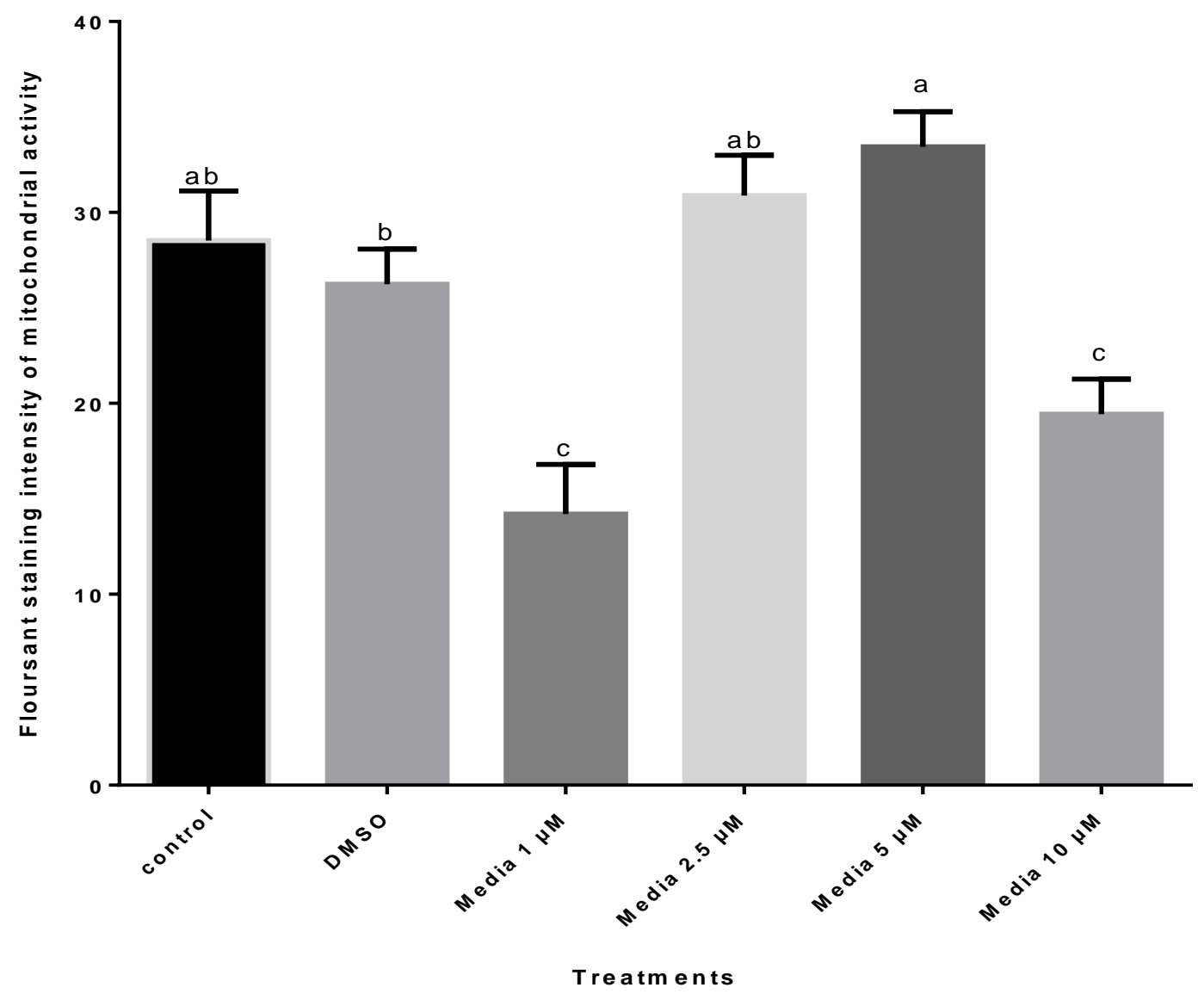

Figure 4. Mitochondrial activity of in vitro cultured granulosa cells treated with different concentrations of curcumin (1, $2.5,5$ and $10 \mu \mathrm{M})$ after $24 \mathrm{~h}$.

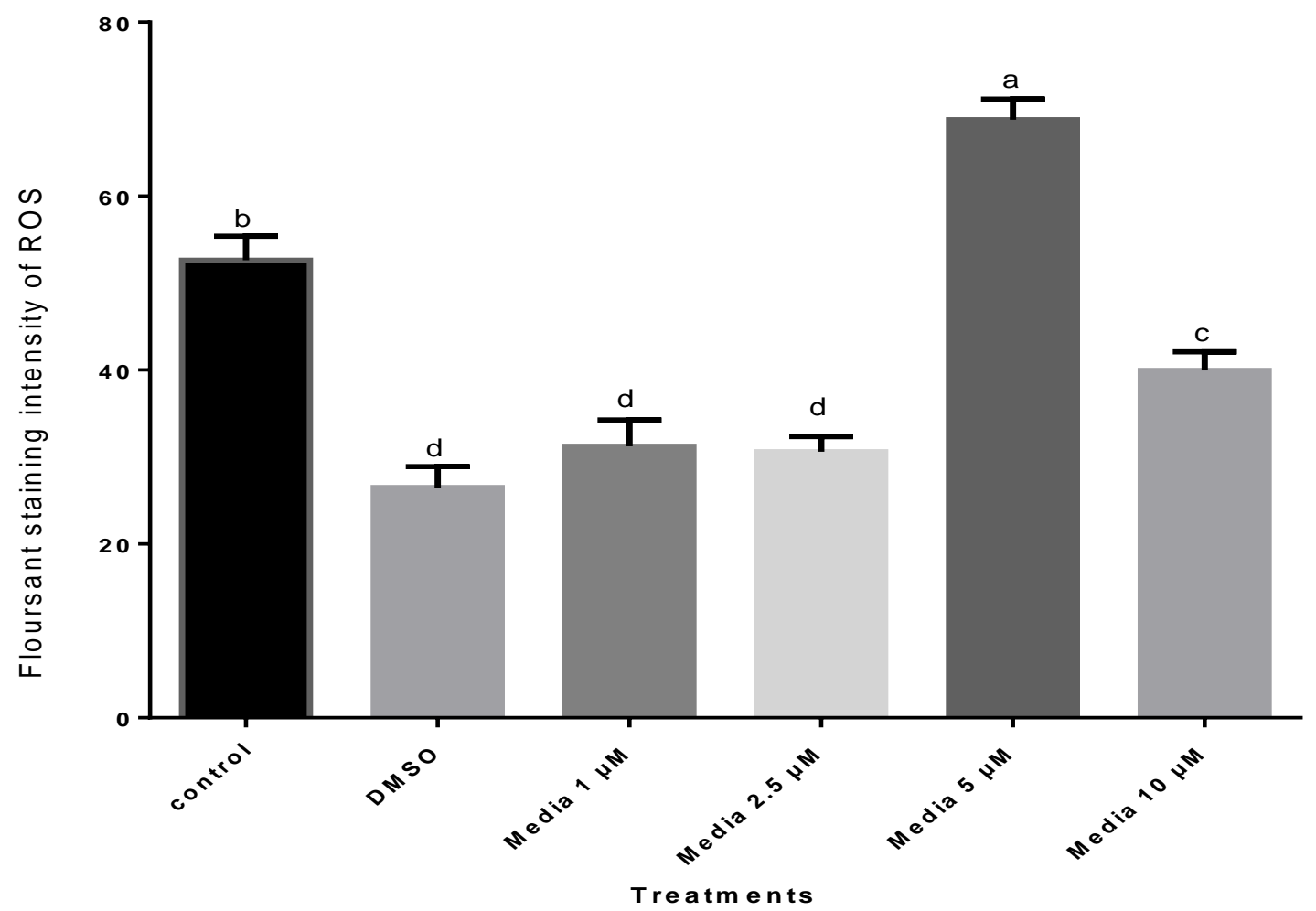

Figure 5. Intracellualr reactive oxygen species level of in vitro cultured granulosa cells treated with different concentrations of curcumin $(1,2.5,5$ and $10 \mu \mathrm{M})$ after $24 \mathrm{~h}$. 


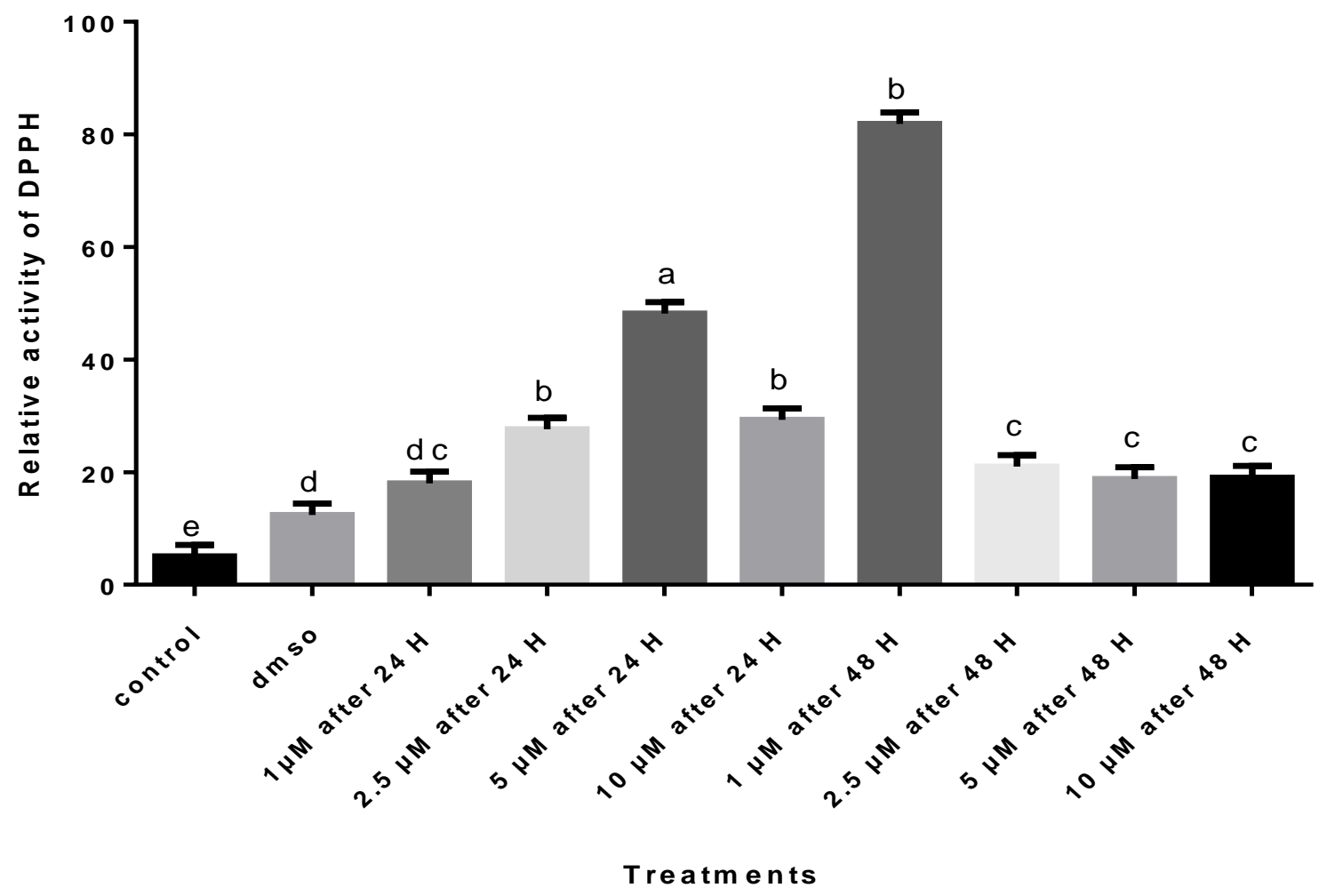

Figure 6. Enzymatic activity of 1,1-diphenyl-2-picrylhydrazyl (DPPH) in in vitro cultured granulosa cells treated with different concentrations of curcumin $(1,2.5,5$ and $10 \mu \mathrm{M})$ after $24 \mathrm{~h}$ and $48 \mathrm{~h}$.

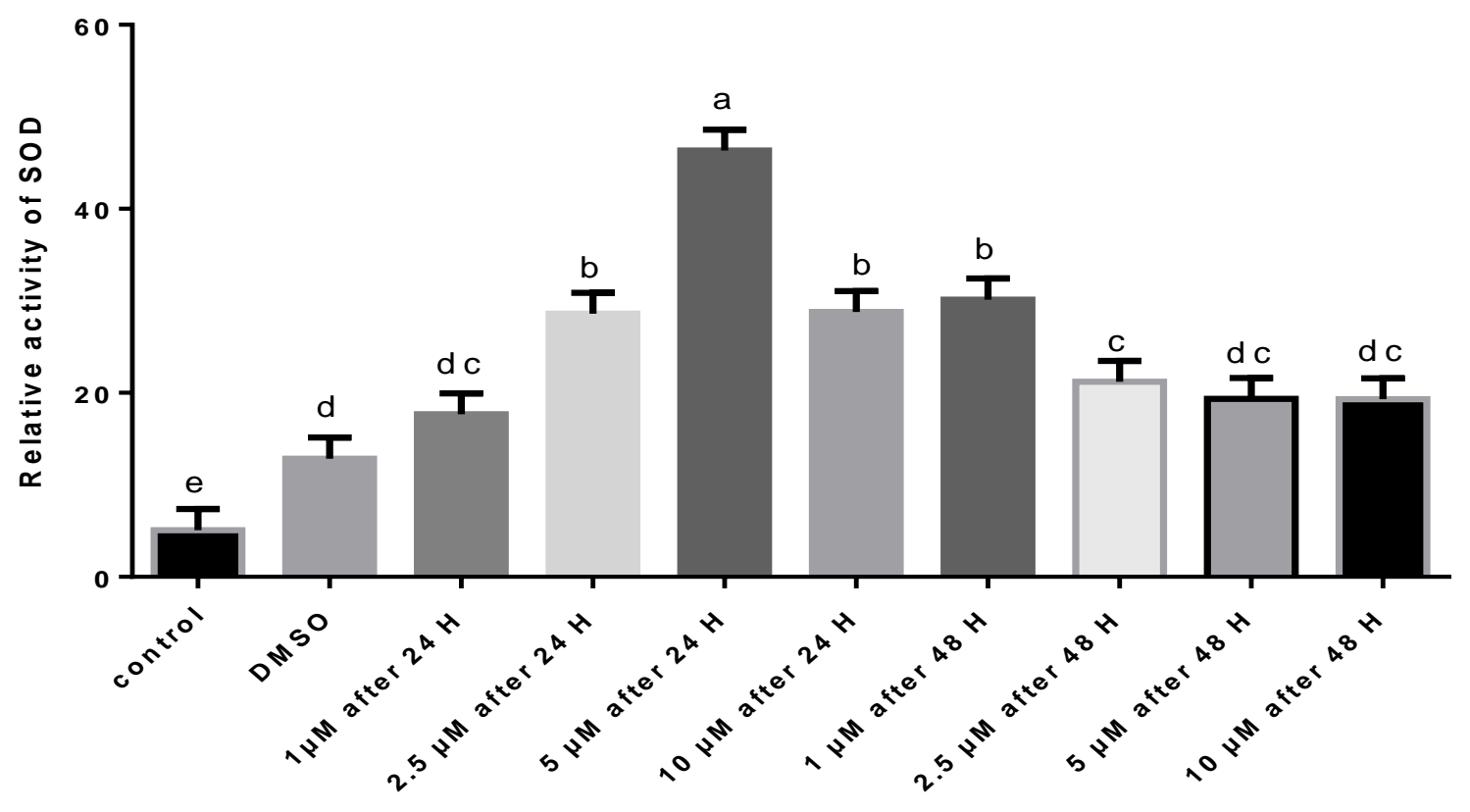

Treatments

Figure 7. Enzymatic activity of superoxide dismutase (SOD) in in vitro cultured granulosa cells treated with different concentrations of curcumin $(1,2.5,5$ and $10 \mu \mathrm{M})$ after $24 \mathrm{~h}$ and $48 \mathrm{~h}$. 


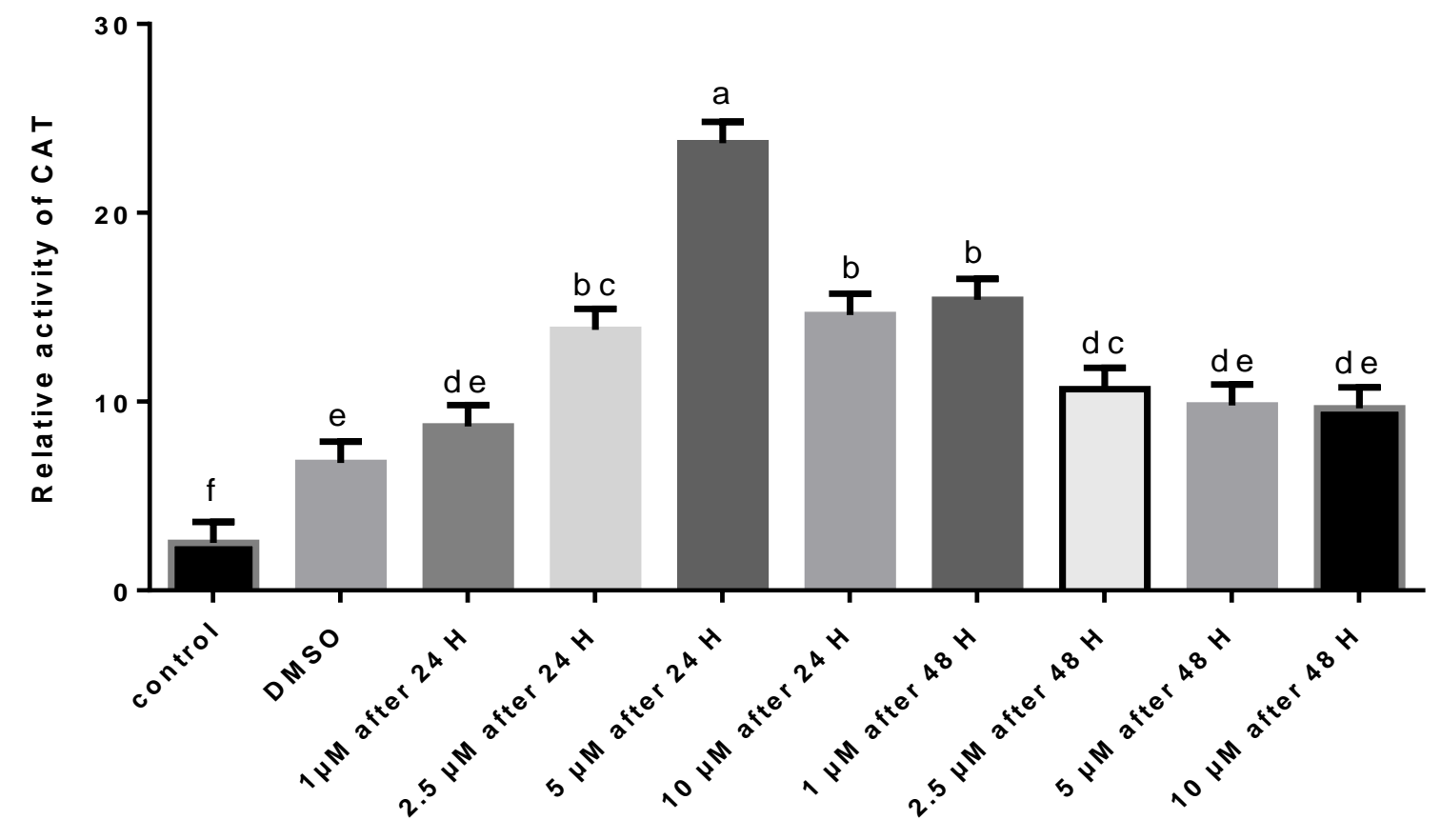

Treatments

Figure 8. Enzymatic activity of catalase (CAT) in in vitro cultured granulosa cells treated with different concentrations of curcumin $(1,2.5,5$ and $10 \mu \mathrm{M})$ after $24 \mathrm{~h}$ and $48 \mathrm{~h}$.

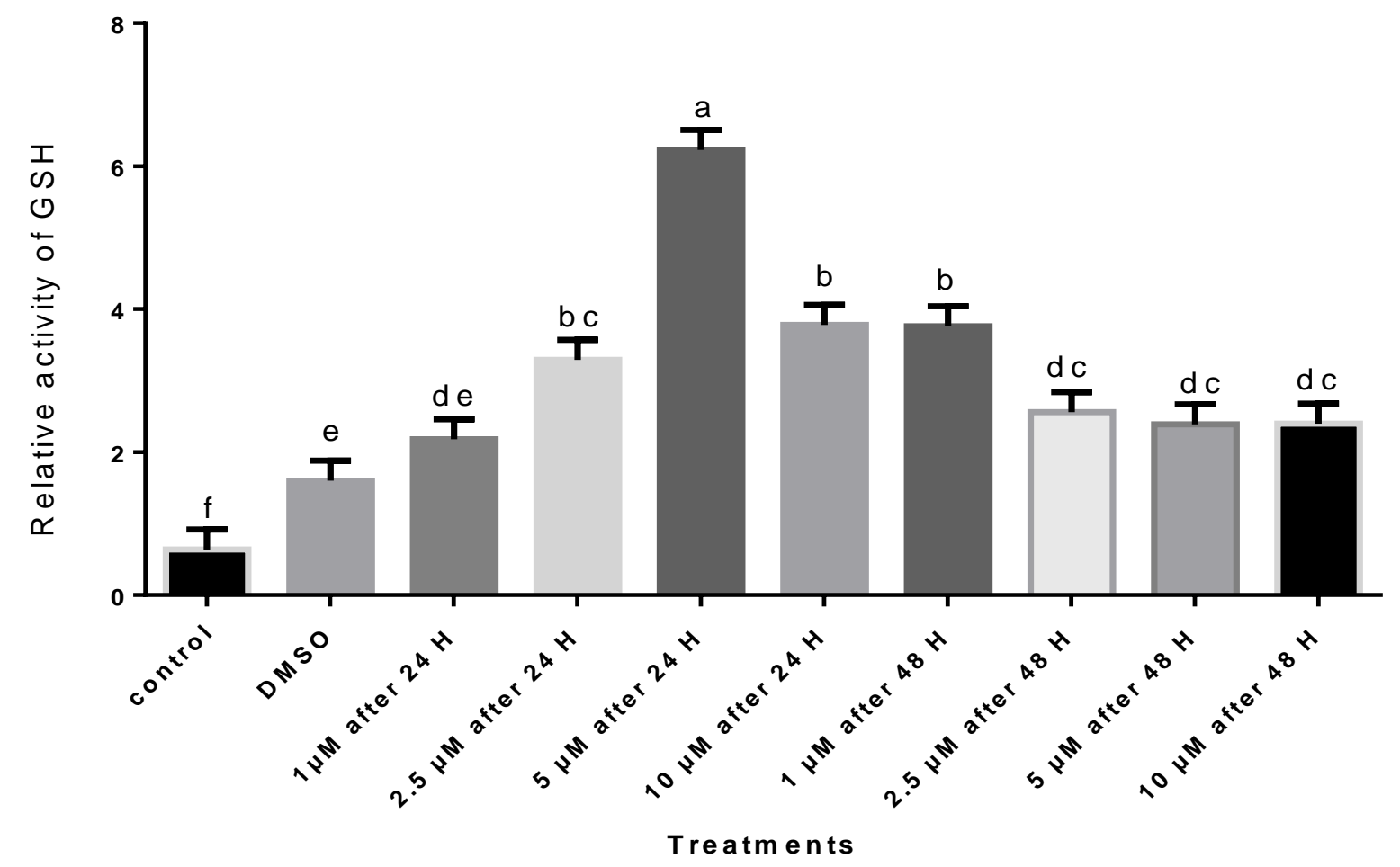

Figure 9. Enzymatic activity of glutatione (GSH) in in vitro cultured granulosa cells treated with different concentrations of curcumin $(1,2.5,5$ and $10 \mu \mathrm{M})$ after $24 \mathrm{~h}$ and $48 \mathrm{~h}$. 


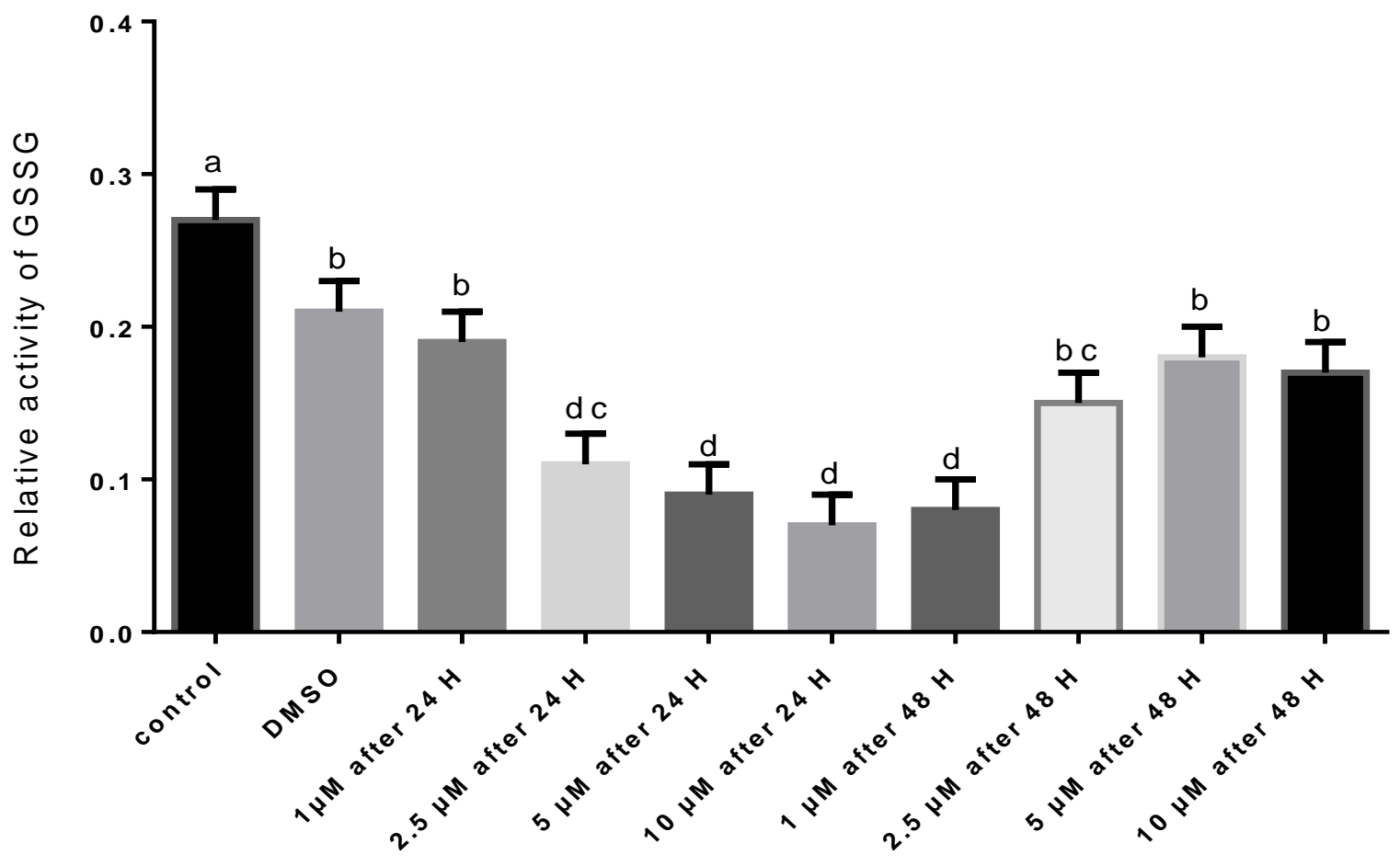

Treatm ents

Figure 10. Enzymatic activity of oxidized glutatione (GSSG) in in vitro cultured granulosa cells treated with different concentrations of curcumin $(1,2.5,5$ and $10 \mu \mathrm{M})$ after $24 \mathrm{~h}$ and $48 \mathrm{~h}$.

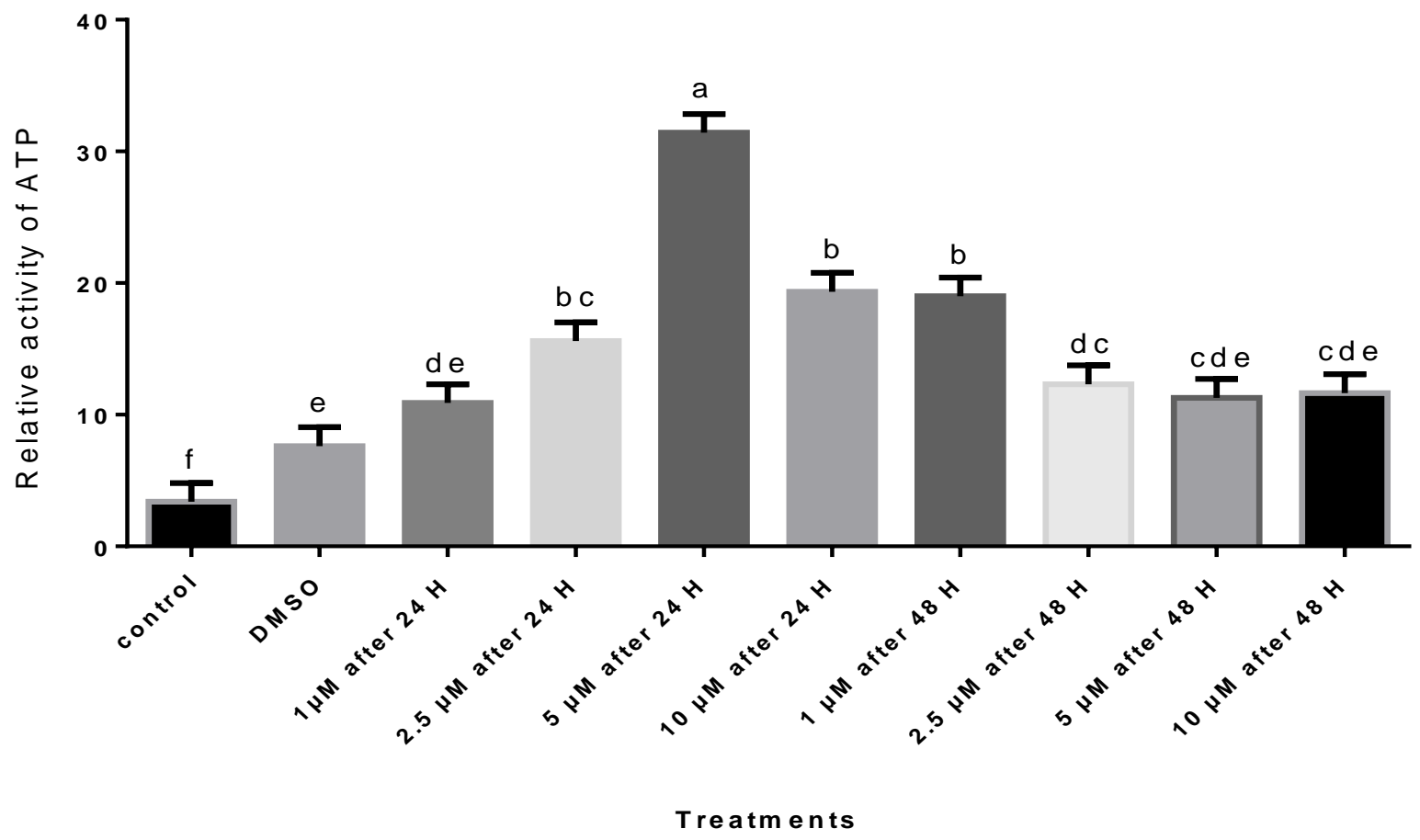

Figure 11. Intracellular adenosine triphosphate (ATP) content in in vitro cultured granulosa cells treated with different concentrations of curcumin $(1,2.5,5$ and $10 \mu \mathrm{M})$ for $24 \mathrm{~h}$ and $48 \mathrm{~h}$. 
Granulosa cells represent ovarian somatic cells that are in direct contact with oocytes. The GCs supports the oocyte via secretory activity, protective and nutritive effects. Therefore, GCs play a major role in acquisition of oocyte development potential and ovulation process (Buccione et al., 1990; Joyce et al., 2001; Su et al., 2009). However, these cells are also affected by oxidative stress that could be induced by ROS produced either by normal metabolic activity or as a result of in vitro culture conditions (Aggarwal et al., 2005). The induction of oxidative stress could subsequently lead to apoptosis of livings cells (Al Dhaheri et al., 2014).

In the current study, the culture medium was supplemented with different concentrations of curcumin to alleviate the excessive ROS accumulated in GCs under in vitro culture condition. Results of the present study indicated reduction of granulosa cells viability cultured on groups treated with DMSO (88.0\%), $1 \mu \mathrm{M}$ curcumin $(86.0 \%), 2.5 \mu \mathrm{M}$ curcumin (86.26\%), $5 \mu \mathrm{M}$ curcumin $(83.0 \%)$ and $10 \mu \mathrm{M}$ curcumin (74.0\%) compared to control group (93.60\%). In accordance with our results, Kádasi et al. (2012 and 2017) reported reduction in growth of in vitro culture swine granulosa cells after curcumin supplementation with 10 and $100 \mu \mathrm{g} \cdot \mathrm{mL}^{-1}$ compared to control and $1 \mu \mathrm{g} \cdot \mathrm{mL}^{-1}$. In addition, it was reported that curcumin down-regulated proliferation of colon cancer cells (Hanif et al., 1997). This negative effect of curcumin in cultured cells is exerted through apoptosis induction (Bhaumik et al., 1999; Liduan et al., 2004; Voznesens' ka et al., 2010). On contrast, Aktas et al. (2012) have shown a positive proliferative effect of curcumin on mice ovarian follicular cells by preventing apoptosis. Indeed, the variation in curcumin effect observed in our study and other investigations could be explained by type of cells under investigations, conditions of culture, dose and duration of treatment (Kádasi et al., 2012 and 2017).

The reduced viability of granulosa cells was coupled with increased level of ROS in groups treated with $5 \mu \mathrm{M}$ of curcumin compared to other experimental groups in the current study. Although, curcumin is a well-known antioxidant (Mantzorou et al., 2018) that is used for reducing incidence of oxidative stress (Santos-Parker et al., 2017). However, high concentration of curcumin could induce cell death (Raza et al., 2008). Nevertheless, when the production of ROS overcomes the cellular antioxidant capability, this may lead to a problem referred to as oxidative stress (Agarwal et al., 2005). The ROS level could be elevated endogenously during many physiological procedures including ovulation (Agarwal et al., 2005). However, during in vitro cell culture, the ROS could be elevated to the level that cause oxidative stress (Rizzo et al., 2012; Castro et al., 2014; Hatami et al., 2014). Interestingly, our results indicated that the level of ROS and mitochondrial activity were elevated on granulosa cells cultured with $5 \mu \mathrm{M}$ of curcumin which was linked with reduced viability of this group, confirming harmful side effects of increasing level of this compound during cell culture. Oxidative stress that occurred due to supplementation of exogenous oxidants has induced apoptosis in different types of mammalian cells, including hepatocytes (Haidara et al., 2002), epithelial cells (Jungas et al., 2002), and fibroblasts (Ran et al., 2004). On the other side, curcumin has maintained the mitochondrial respiratory function as well as redox status of PC12 cell line without influencing ROS and viability of cells (Raza et al., 2008). This in accordance with our results that demonstrated increased mitochondrial activity and ATP content in GCs supplemented with curcumin for $24 \mathrm{~h}$ during in vitro culture however, that was coupled with reduced cellular viability.

Several intracellular enzymes comprise the defense systems of mammalian cells. For example, SOD, GPX1 and CAT, GSSG and DPPH are contributing to scavenging capacity of cells to reduce the harmful effects of oxidative stress induced by ROS (Qin et al., 2015). In the current study, the enzyme activity of CAT, SOD, GSH and DPPH was increased after treating cultured granulosa cells with $5 \mu \mathrm{M}$ of curcumin however all these enzymes were declined significantly reduced after $48 \mathrm{~h}$. A recent study done by Qin et al., (2015) demonstrated a protective effect of curcumin on alleviating oxidative stress of porcine granulosa cells by rescuing the activity of antioxidant enzymes. However, the present study indicated that although curcumin increase the level of different antioxidant enzymes after $24 \mathrm{~h}$ of in vitro cell culture but it could not sustain this biological action after $48 \mathrm{~h}$ and cell viability was reduced due to increased ROS level.

\section{CONCLUSION}

The present findings indicated negative effect of in vitro culture on granulosa cell viability and redox status. Antioxidant compound namely curcumin increased the negative effect of in vitro culture when added at higher concentration (10 $\mu \mathrm{M})$. However, low concentration $(2.5 \mu \mathrm{M})$ of curcumin could maintain metabolic activity as well as defense system by up-regulation of antioxidant enzymes for short duration.

\section{DECLARATIONS}

Author's contributions

All authors have contributed to Lab work, the experimental design, writing and revision of the manuscript. 
Acknowledgement

All authors express their thanks to Ms/Fatma Sultan for her technical assistance during in vitro culture of GCs.

\section{Competing interests}

All authors declare no competing interests that might interfere with the data provided in the current manuscript.

\section{Consent to publish}

All the authors approved and agreed to publish the manuscript.

\section{REFERENCES}

Aebi H (1984). Catalase in vitro, In: methods in enzymology. Elsevier, pp. 121-126

Agarwal A, Aponte-Mellado A, Premkumar BJ, Shaman A and Gupta S (2012). The effects of oxidative stress on female reproduction: a review. Reproductive Biology and Endocrinology, 10 (1): 49. DOI: http://dx.doi.org/10.1186/1477-7827-10-49.

Agarwal A, Gupta S and Sharma RK (2005). Role of oxidative stress in female reproduction. Reproductive Biology and Endocrinology, 3 (1): 28. DOI: http://dx.doi.org/10.1186/1477-7827-3-28.

Aggarwal BB, Kumar A, Aggarwal MS and Shishodia S (2005). Curcumin derived from turmeric (Curcuma longa): a spice for all seasons. Phytopharmaceuticals in Cancer Chemoprevention, 23: 351-387. Available at: http://www.sciepub.com/reference/38129

Aggarwal BB ,Sundaram C, Malani N and Ichikawa H (2007). Curcumin: the Indian solid gold, In: The molecular targets and therapeutic uses of curcumin in health and disease. Springer, pp. 1-75. DOI: http://dx.doi.org/10.1007/978-0-387-46401-5_1

Aktas C, Kanter M and Kocak Z (2012). Antiapoptotic and proliferative activity of curcumin on ovarian follicles in mice exposed to whole body ionizing radiation. Toxicology and Industrial Health, 28 (9): 852-863. DOI: http://dx.doi.org/10.1177/0748233711425080

Al Dhaheri Y, Attoub S, Ramadan G, Arafat K, Bajbouj K, Karuvantevida N, AbuQamar S, Eid A and Iratni R (2014). Carnosol induces ROSmediated beclin1-independent autophagy and apoptosis in triple negative breast cancer. PLoS One, 9 (10): e109630. DOI: http://dx.doi.org/10.1371/journal.pone.0109630.

Barzegar A and Moosavi-Movahedi AA (2011). Intracellular ROS protection efficiency and free radical-scavenging activity of curcumin, PLoS One, 6 (10): e26012. DOI: http://dx.doi.org/10.1371/journal.pone.0026012.

Bhaumik S, Anjum R, Rangaraj N, Pardhasaradhi BV and Khar A (1999). Curcumin mediated apoptosis in AK-5 tumor cells involves the production of reactive oxygen intermediates. Federation of European Biochemical Societies, 456 (2): 311-314. DOI: http://dx.doi.org/10.1016/s00145793(99)00969-2.

Blois MS (1958). Antioxidant determinations by the use of a stable free radical. Nature, 181 (4617): 1199-1200. DOI: http://dx.doi.org/10.1371/journal.pone.0026012

Buccione R, Vanderhyden B, Caron PJ and Eppig JJ (1990). FSH-induced expansion of the mouse cumulus oophorus in vitro is dependent upon a specific factor(s) secreted by the oocyte. Developmental Biology, 138 (1): 16-25. DOI: http://dx.doi.org/10.1016/0012-1606(90)90172-f.

Castro SV, Carvalho AA, Silva CM, Santos FW, Campello CC, de Figueiredo JR and Rodrigues AP (2014). Frozen and fresh ovarian tissue require different culture media to promote in vitro development of bovine preantral follicles. Biopreservation and Biobanking, 12 (5): $317-324$. DOI: http://dx.doi.org/10.1089/bio.2014.0020.

Cinar MU and Sohel MMH (2015). Advancement in Molecular Genetics to understand the molecular reproduction of Livestock - follicular development. Research in Agriculture Livestock and Fisheries, 1 (1): 47-60. DOI: http://dx.doi.org/10.3329/ralf.v1i1.22355.

Correa F, Buelna-Chontal M, Hernandez-Resendiz S, Garcia-Nino WR, Roldan FJ ,Soto V, Silva-Palacios A, Amador A, Pedraza-Chaverri J, Tapia E and Zazueta C (2013). Curcumin maintains cardiac and mitochondrial function in chronic kidney disease. Free Radical Biology and Medicine, 61: 119-129. DOI: http://dx.doi.org/10.1016/j.freeradbiomed.2013.03.017.

Dinkova-Kostova AT and Talalay P (2008). Direct and indirect antioxidant properties of inducers of cytoprotective proteins. Molecular Nutrition Food Research, 52(S1): S128-S138. DOI: https://doi.org/10.1002/mnfr.200700195.

Duffy DM and Stouffer RL (2003). Luteinizing hormone acts directly at granulosa cells to stimulate periovulatory processes: modulation of luteinizing hormone effects by prostaglandins. Endocrine, 22 (3): 249-256. DOI: http://dx.doi.org/10.1385/endo:22:3:249.

Epstein J ,Sanderson IR and Macdonald TT (2010). Curcumin as a therapeutic agent: the evidence from in vitro, animal and human studies. British Journal of Nutrition, 103 (11): 1545-1557. DOI: http://dx.doi.org/10.1017/S0007114509993667.

Esatbeyoglu T, Huebbe P, Ernst IM, Chin D, Wagner AE and Rimbach G (2012). Curcumin--from molecule to biological function. Angewandte Chemmie International Edition, 51 (22): 5308-5332. DOI: http://dx.doi.org/10.1002/anie.201107724.

Frisard M and Ravussin E (2006). Energy metabolism and oxidative stress: impact on the metabolic syndrome and the aging process. Endocrine, 29 (1): 27-32. DOI: http://dx.doi.org/10.1385/ENDO:29:1:27.

Haidara K, Morel I, Abalea V, Gascon Barre M and Denizeau F (2002). Mechanism of tert-butylhydroperoxide induced apoptosis in rat hepatocytes: involvement of mitochondria and endoplasmic reticulum. Biochimica et Biophysica Acta (BBA) . Molecular Cell Research, 1542(1-3): 173-185. DOI: http://dx.doi.org/10.1016/s0167-4889(01)00178-1.

Hanif R, Qiao L, Shiff SJ and Rigas B (1997). Curcumin, a natural plant phenolic food additive, inhibits cell proliferation and induces cell cycle changes in colon adenocarcinoma cell lines by a prostaglandin-independent pathway. Journal of Laboratory and Clinical Medicine, 130 (6): 576584. DOI: http://dx.doi.org/10.1016/s0022-2143(97)90107-4.

Hatami S, Zavareh S, Salehnia M, Lashkarbolouki T and Karimi I (2014). Comparison of oxidative status of mouse pre-antral follicles derived from vitrified whole ovarian tissue and vitrified pre-antral follicles in the presence of alpha lipoic acid. Journal of Obstetrics and Gynaecology Research, 40 (6): 1680-1688. DOI: http://dx.doi.org/10.1111/jog.12394. 
Hatcher H, Planalp R, Cho J, Torti FM, and Torti SV (2008). Curcumin: from ancient medicine to current clinical trials. Cellular and Molecular Life Sciences, 65(11): 1631-1652. https://doi.org/10.1007/s00018-008-7452-4.

Jayatilleke E and Shaw S (1993). A high-performance liquid chromatographic assay for reduced and oxidized glutathione in biological samples. Analytical Biochemistry, 214 (2): 452-457. DOI: http://dx.doi.org/10.1006/abio.1993.1522.

Joyce IM, Pendola FL, O'Brien M and Eppig JJ (2001). Regulation of prostaglandin-endoperoxide synthase 2 messenger ribonucleic acid expression in mouse granulosa cells during ovulation. Endocrinology, 142 (7): 3187-3197. DOI: http://dx.doi.org/10.1210/endo.142.7.8268.

Jungas T, Motta I, Duffieux F, Fanen P, Stoven V and Ojcius DM (2002). Glutathione levels and BAX activation during apoptosis due to oxidative stress in cells expressing wild-type and mutant cystic fibrosis transmembrane conductance regulator. The Journal of Biological Chemistry, 277 (31): 27912-27918. DOI: http://dx.doi.org/10.1074/jbc.M110288200.

Kádasi A, Maruniakova N, Stochmalova A, Bauer M, Grossmann R, Harrath AH, Kolesarova A and Sirotkin AV (2017). Direct effect of curcumin on porcine ovarian cell functions. Animal Reproduction Science, 182: 77-83. DOI: http://dx.doi.org/10.1016/j.anireprosci.2017.05.001.

Kádasi A, Sirotkin AV, Maruniaková N, Kolesárová A, Bulla J and Grossmann R (2012). The effect of curcumin on secretory activity, proliferation and apoptosis of the porcine ovarian granulosa cells. The Journal of Microbiology, Biotechnology and Food Sciences, 2(1): 349. DOI: http://dx.doi.org/10.1016/j.anireprosci.2017.05.001

Klaunig JE, Kamendulis LM and Hocevar BA (2010). Oxidative stress and oxidative damage in carcinogenesis. Toxicologic Pathology, 38 (1): 96-109. DOI: http://dx.doi.org/10.1177/0192623309356453.

Liu G, Xiang T, Wu QF and Wang WX (2016). Curcumin suppresses the proliferation of gastric cancer cells by downregulating H19. Oncology Letters, 12(6): 5156-5162. DOI: http://dx.doi.org/10.3892/ol.2016.5354.

Mantzorou M, Pavlidou E, Vasios G,Tsagalioti E and Giaginis C (2018). Effects of curcumin consumption on human chronic diseases: A narrative review of the most recent clinical data. Phytotherapy Research, 32 (6): 957-975. DOI: http://dx.doi.org/10.1002/ptr.6037.

Marklund S and Marklund G (1974). Involvement of the superoxide anion radical in the autoxidation of pyrogallol and a convenient assay for superoxide dismutase. European Journal of Biochemistry, 47 (3): 469-474. DOI: http://dx.doi.org/10.1111/j.1432-1033.1974.tb03714.x.

Mohebbati R, Anaeigoudari A, Khazdair MR (2017). The effects of Curcuma longa and curcumin on reproductive systems. Endocrine Regulations, 51(4): 220-228. DOI: http://dx.doi.org/10.1515/enr-2017-0024

Nadkarni K (2007). Indian Materia Medica, Ed. Bombay Popular Mumbai, 1: 691-694. Available at: https://trove.nla.gov.au/work/18643838?q\&versionId=21887031.

Panieri E and Santoro M (2016). ROS homeostasis and metabolism: a dangerous liason in cancer cells. Cell Death \& Disease 7, e2253. DOI: https://doi.org/10.1038/cddis.2016.105

Pinkus R ,Weiner LM and Daniel V (1996). Role of oxidants and antioxidants in the induction of AP-1, NF-kappaB, and glutathione S-transferase gene expression. The Journal of Biological Chemistry, 271 (23): 13422-13429. DOI: http://dx.doi.org/10.1074/jbc.271.23.13422.

Prastowo S, Amin A, Rings F, Held E, Wondim DS, Gad A, Neuhoff C, Tholen E, Looft C, Schellander K and Tesfaye D (2016). Fateful triad of reactive oxygen species, mitochondrial dysfunction and lipid accumulation is associated with expression outline of the AMP-activated protein kinase pathway in bovine blastocysts. Reproduction, Fertility and Development, 29 (5): 890-905. DOI: http://dx.doi.org/10.1071/RD15319.

Qin X, Cao M, Lai F, Yang F, Ge W, Zhang X, Cheng S, Sun X, Qin G, Shen W and Li L (2015). Oxidative stress induced by zearalenone in porcine granulosa cells and its rescue by curcumin in vitro. PLoS One, 10 (6): e0127551. DOI: http://dx.doi.org/10.1371/journal.pone.0127551.

Ran Q, Liang H, Gu M, Qi W, Walter CA, Roberts LJ, Herman B, Richardson A and Van Remmen H (2004). Transgenic mice overexpressing glutathione peroxidase 4 are protected against oxidative stress-induced apoptosis. The journal of Biological Chemistry, 279 (53): $55137-55146$. DOI: http://dx.doi.org/10.1074/jbc.M410387200.

Raza H, John A, Brown EM, Benedict S and Kambal A (2008). Alterations in mitochondrial respiratory functions, redox metabolism and apoptosis by oxidant 4-hydroxynonenal and antioxidants curcumin and melatonin in PC12 cells. Toxicology and Applied Pharmacology, 226 (2): 161-168. DOI: http://dx.doi.org/10.1016/j.taap.2007.09.002.

Repetto G, Del Peso A and Zurita JL (2008). Neutral red uptake assay for the estimation of cell viability/cytotoxicity. Nature Protocols, 3 (7): $1125-$ 1131. DOI: http://dx.doi.org/10.1038/nprot.2008.75.

Reyes-Fermin LM, Gonzalez-Reyes S, Tarco-Alvarez NG, Hernandez-Nava M, Orozco-Ibarra M and Pedraza-Chaverri J (2012). Neuroprotective effect of alpha-mangostin and curcumin against iodoacetate-induced cell death. Nutritional Neuroscience, 15 (5): 34-41. DOI: http://dx.doi.org/10.1179/1476830512Y.0000000011.

Rueden CT, Schindelin J, Hiner MC, DeZonia BE, Walter AE, Arena ET and Eliceiri KW (2017). ImageJ2: ImageJ for the next generation of scientific image data. BMC Bioinformatics, 18(1): 529. doi:10.1186/s12859-017-1934-Z

Santos-Parker JR, Strahler TR, Bassett CJ, Bispham NZ, Chonchol MB and Seals DR (2017). Curcumin supplementation improves vascular endothelial function in healthy middle-aged and older adults by increasing nitric oxide bioavailability and reducing oxidative stress. Aging (Albany NY), 9 (1): 187-208. DOI: http://dx.doi.org/10.18632/aging.101149.

Shkolnik K, Tadmor A, Ben-Dor S, Nevo N, Galiani D and Dekel N (2011). Reactive oxygen species are indispensable in ovulation. Proceedings of the National Academy of Sciences, 108 (4): 1462-1467. DOI: http://dx.doi.org/10.1073/pnas.1017213108.

Sohel MM, Hoelker M, Noferesti SS, Salilew-Wondim D, Tholen E, Looft C, Rings F, Uddin MJ, Spencer TE, Schellander K and Tesfaye D (2013). Exosomal and Non-Exosomal Transport of Extra-Cellular microRNAs in Follicular Fluid: Implications for Bovine Oocyte Developmental Competence. PLoS One, 8 (11): e78505. DOI: http://dx.doi.org/10.1371/journal.pone.0078505.

Sohel MMH, Konca Y, Akyuz B, Arslan K, Sariozkan S and Cinar MU (2017). Concentration dependent antioxidative and apoptotic effects of sulforaphane on bovine granulosa cells in vitro. Theriogenology, 97:17-26. DOI: 10.1016/j.theriogenology.2017.04.015.

Steward WP and Gescher AJ (2008). Curcumin in cancer management: recent results of analogue design and clinical studies and desirable future research. Molecular Nutrition \& Food research, 52 (9): 1005-1009. DOI: http://dx.doi.org/10.1002/mnfr.200700148.

Strober W (2015). Trypan blue exclusion test of cell viability. Current protocols in immunology, 111:A3.B.1-A3.B.3. DOI: http://dx.doi.org/10.1002/0471142735.ima03bs111. 
Su YQ, Sugiura K and Eppig JJ (2009). Mouse oocyte control of granulosa cell development and function: paracrine regulation of cumulus cell metabolism, In: Seminars in Reproductive Medicine, 27 (1): 32-42. DOI: https://doi.org/10.1055/s-0028-1108008

Sung B, Prasad S, Yadav VR and Aggarwal BB (2012). Cancer cell signaling pathways targeted by spice-derived nutraceuticals. Nutrition and cancer, 64 (2): 173-197. DOI: http://dx.doi.org/10.1080/01635581.2012.630551.

Tapia E, Soto V, Ortiz-Vega K M, Zarco-Marquez G, Molina-Jijon E, Cristobal-Garcia M, Santamaria J, Garcia-Nino WR, Correa F, Zazueta C and Pedraza-Chaverri J (2012). Curcumin induces Nrf2 nuclear translocation and prevents glomerular hypertension, hyperfiltration, oxidant stress, and the decrease in antioxidant enzymes in 5/6 nephrectomized rats. Oxidative medicine and cellular longevity, 2012: 269039. DOI: http://dx.doi.org/10.1155/2012/269039.

Tapia E, Zatarain-Barron ZL, Hernandez-Pando R, Zarco-Marquez G, Molina-Jijon E, Cristobal-Garcia M, Santamaria J and Pedraza-Chaverri J (2013). Curcumin reverses glomerular hemodynamic alterations and oxidant stress in 5/6 nephrectomized rats. Phytomedicine, 20 (3-4): $359-366$. DOI: http://dx.doi.org/10.1016/j.phymed.2012.11.014.

Teerlink T, Hennekes M, Bussemaker J and Groeneveld J (1993). Simultaneous determination of creatine compounds and adenine nucleotides in myocardial tissue by high-performance liquid chromatography. Analytical Biochemistry, 214 (1): 278-283. DOI: http://dx.doi.org/10.1006/abio.1993.1488.

Trujillo J, Chirino YI, Molina-Jijon E, Anderica-Romero AC, Tapia E and Pedraza-Chaverri J (2013). Renoprotective effect of the antioxidant curcumin: Recent findings. Redox Biology, 1 (1): 448-456. DOI: http://dx.doi.org/10.1016/j.redox.2013.09.003.

Voznesens'ka T, Bryzhina TM, Sukhina VS, Makohon NV and Aleksieieva IM (2010). Effect of NF-kappaB activation inhibitor curcumin on the oogenesis and follicular cell death in immune ovarian failure in mice. Fiziolohichnyi Zhurnal, 56 (4): 96-101. DOI: http://dx.doi.org/10.15407/fz56.04.096.

Yada H, Hosokawa K, Tajima K, Hasegawa Y and Kotsuji F (1999). Role of ovarian theca and granulosa cell interaction in hormone productionand cell growth during the bovine follicular maturation process. Biology of Reproduction, 61 (6): 1480-1486. DOI: http://dx.doi.org/10.1095/biolreprod61.6.1480.

Zheng L, Tong Q and Wu C (2004). Growth-inhibitory effects of curcumin on ovary cancer cells and its mechanisms. Journal of Huazhong University of Science and Technology, 24 (1): 55-58. DOI: http://dx.doi.org/10.1007/bf02830706.

Zhang Y, Huang Y, Deng H and Huang X (2019a). Curcumin attenuates oxidative stress in RAW264.7 cells by increasing the activity of antioxidant enzymes and activating the Nrf2-Keap1 pathway. PLoS One, 14(5): e216711. DOI: http://dx.doi.org/10.1371/journal.pone.0216711.

Zhang Y, Lin XY, Zhang JH, Xie ZL, Deng H, Huang YF and Huang XH (2019b). Apoptosis of mouse myeloma cells induced by curcumin via the Notch3-p53 signaling axis. Oncology Letters, 17(1):127-134. DOI:http://dx.doi.org/ 10.3892/ol.2018.9591.

Zhu G, Shen Q, Jiang H, Ji O, Zhu L and Zhang L (2020). Curcumin inhibited the growth and invasion of human monocytic leukaemia SHI1 cells in vivo by altering MAPK and MMP signalling. Pharmacy Biology, 58(1):25-34. DOI: http://dx.doi.org/10.1080/13880209. 